\title{
Brug af et content management system i sprog- og kommunikationsundervisningen
}

\author{
Lill Ingstad \\ Studielektor \\ Engelsk Institut \\ Copenhagen Business School \\ li.eng@cbs.dk
}

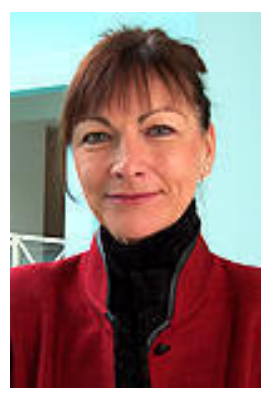

Henrik Køhler Simonsen

Adjunkt, Ph.d., erhvervsforsker

Engelsk Institut

Copenhagen Business School

hks.eng@cbs.dk

www.telelex.dk

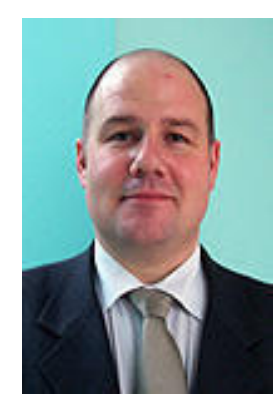

Lill Ingstad er studielektor ved Engelsk Institut, Copenhagen Business School og fagansvarlig for BA-uddannelsen i engelsk. Lill underviser i interkulturel erhvervskommunikation, engelsk virksomhedskommunikation og økonomisk sprog og arbejder med udvikling og koordinering af Engelsk Instituts undervisning i fagsprog på BA.

Henrik Køhler Simonsen er adjunkt ved Engelsk Institut, Copenhagen Business School og forsker i virksomhedsleksikografi. Henrik underviser i engelsk virksomhedskommunikation, web writing, technical communication, corporate language policy samt IT og har stor erfaring med anvendelse af IT og sprogteknologi i undervisning, forskning og praksis.

\section{Indledning}

Der er vist ingen tvivl om, at sprog- og kommunikationsundervisningen på de danske universiteter allerede har gennemgået voldsomme forandringer i de senere år, men det er nok også et faktum, at disse fag i endnu højere grad er stillet over for store udfordringer de kommende år. Udfordringerne består blandt andet i at gøre sprog- og kommunikationsundervisningen mere erhvervsrettet, praksisnær, vedkommende og teknologibaseret, hvilket fx anbefalinger fra Ministeriet for Videnskab, Teknologi og Udvikling peger på, jf. (VTU, 2005:5).

Derudover har Dansk Industri i 2004 udarbejdet undersøgelsen Behov for globale kompetencer (Anderskouv og Mikkelsen, 2004a-c), hvor en række danske virksomheder blev bedt om at vurdere kvaliteten af nyuddannede med en videregående uddannelse. Af undersøgelsen fremgik det, at nyuddannede generelt mangler faglige kompetencer som forretningsforståelse, resultatskabelse, kommunikative evner (herunder sprogkundskaber) og fleksibilitet. 
Samtidig er der simpelthen bare på mange universiteter behov for i større udstrækning at inddrage mere og bedre teknologi, især i sprog- og kommunikationsundervisningen, fordi forskellige former for teknologi nu i langt højere grad end tidligere er en naturlig del af de studerendes hverdag. Unge mennesker i dag synes at være meget teknologifikserede, hvilket en undersøgelse af 5.000 teenagere i Nordamerika lavet af Forrester Research i øvrigt også viser, jf. (Taylor, 2005). Blandt andet derfor har de studerende ofte en forventning om, at studierne understøttes af teknologi.

Alt dette - og det helt åbenlyse behov for kandidater med kulturkendskab og fremmedsprogsbeherskelse på højt niveau, jf. (Anderskouv og Mikkelsen, 2004a-c) - betyder, at vi må gøre noget. For at imødekomme erhvervslivets såvel som de studerendes behov har vi brug for nytænkning. Det gælder både undervisningsmateriale og tilrettelæggelse af kurser. Det er vigtigt, at vi videreudvikler brugen af it på universiteterne, således at e-læringsplatforme bruges til andet og mere end blot at lette den praktiske administration af et studie- eller kursusforløb.

Gennem længere tid har vi på Institut for Engelsk på Copenhagen Business School overvejet, hvorledes vi kan tilpasse vores kurser i sprog og kommunikation til de behov, virksomhederne og organisationerne har i dag, og til vores studerendes behov og forudsætninger. En lille projektgruppe har arbejdet med anvendelse af et content management system i undervisningen, og denne artikel vil kort redegøre for de pædagogiske og tekniske overvejelser, der ligger forud for implementeringen af et case-forløb, som blev afviklet via et content management system.

\section{Didaktiske/pædagogiske overvejelser}

Et eksempel på et forsøg på at forholde sig til den nye situation er det oplæg til en læringsstrategi for Copenhagen Business School, som CBS Learning Lab har udarbejdet. I oplægget fokuseres der bl.a. på følgende (CBS Learning Lab, 2005, ss. 6-10):

Vedrørende læreprocessen:

Læring sker, når studerende tilegner sig ny viden, færdigheder og kompetencer, som kan anvendes til løsning af kommende udfordringer i livet.

- Enhver samling af studerende, undervisere, teknologier/medier konstituerer en ny læringskontekst, der har konkret betydning for den studerendes læreproces.

Vedrørende dannelsesidealet:

- CBS-dimittender besidder både kernefaglighed og tværfaglighed.

- CBS-dimittender kan arbejde anvendelsesorienteret og praksisnært.

- CBS-dimittender har personlige og interpersonelle kompetencer forstået som almene kvalifikationer, der er nødvendige for at kunne begå sig i et videregående studium samt begå sig i erhvervsfunktioner i samfundet - nationalt såvel som internationalt.

- CBS-dimittender er handlekraftige.

Vedrørende principper for udformning af studier og studieaktiviteter:

- Der anvendes en blanding af varierede, aktiverende studieelementer.

- Uddannelserne er praksisrelaterede og problemorienterede.

- Informations- og kommunikationsteknologi (IKT) anvendes, hvor det fremmer de studerendes læreprocesser eller letter kommunikationen mellem studerende, undervisere og administration. 
Det er oplagt, at undervisningsmateriale i form af online cases, ville kunne dække mange af de nye krav og behov i forbindelse med sprog- og kommunikationsundervisning, som traditionelle lærebøger og andet undervisningsmateriale ikke dækker tilfredsstillende.

Anvendelsesorienterede og praksisnære caseopgaver klæder de studerende på til at kunne løse kommende udfordringer i erhvervsfunktioner i samfundet. I caseopgaver har man mulighed for at tilbyde de studerende varierede, aktiverende og problemorienterede opgaver sat ind i en erhvervsmæssig kontekst.

Caseopgaver lægger ud over kernefaglighed også helt naturligt op til tværfaglige opgaveløsninger på en instruktiv og virklighedsnær måde og opøver de studerendes handlekraft ved hjælp af praktiske problemorienterede opgaver.

Ved at indarbejde caseopgaverne i et elektronisk medie faciliteres desuden videndeling og kommunikation mellem studerende, undervisere og eventuelle opdragsgivere i erhvervslivet.

På den baggrund er vi gået i gang med at udvikle en CMS-baseret online case-virksomhed. Den grundlæggende idé i udviklingsprojektet er at tilbyde de studerende 'job' i en case-virksomhed på nettet, hvor de dels skal vedligeholde og oparbejde virksomhedens websider på internettet (på dansk og engelsk), dels får forskellige arbejdsopgaver tildelt på virksomhedens intranet. Disse opgaver kunne være produktionsopgaver (fx oversættelser, tekstproduktion, revision) eller problemløsningsopgaver (fx kommunikationsstrategier, målgruppeanalyser, udarbejdelse af sprogpolitik, informationssøgning og lignende).

Overordnet skal casen bidrage til at give de studerende indsigt i bl.a. følgende hovedområder:

- virksomheders struktur; typiske kommunikationsgange og -typer,

- videndeling og videndelingsværktøjer,

- sprog og kommunikation på højt niveau i en praktisk kontekst,

- genrekarakteristika,

- engelsk som lingua franca i en interkulturel global kontekst.

Når casen er færdigudviklet er det meningen, at den skal lægge op til, at de studerende kan arbejde tværfagligt i studierne, fx sprog og kommunikation kombineret med markedsføring. Dermed kan systemet skabe en klarere sammenhæng, fx i kombinationsuddannelser. Selve systemet skal være så let at arbejde med, at undervisere og studerende selv skal kunne videreudvikle case-konteksten og tilføje nye elementer og problemstillinger.

Rent administrativt er systemet fleksibelt, da det alt efter ønske kan styres centralt (fx på institutionsniveau), af den enkelte lærer eller af de studerende.

Vi mener, at denne type af undervisningsmateriale falder i tråd med de ønsker og behov, virksomheder og studerende har. Projektet skaber merværdi for stort set alle tænkbare interessenter:

\section{Pædagogisk merværdi}

- Casen understøtter processuel læring i en konkret kontekst og indbyder til interaktion og videndeling mellem de involverede parter - studerende, lærere og virksomheder. 
- Ud over at skabe 'viden', skaber case-formen også 'kunnen', da den forudsætter produktion på grundlag af et antal indarbejdede opgaver.

- Casen skaber og understøtter en god kobling mellem teori og praksis.

- Mulighed for at arbejde i praksisfællesskaber på tværs af uddannelsen, således at man kan opnå en synergieffekt ved at dele ekspertise med andre, der har interesse i samme projekt/arbejdsopgave (Wenger og Snyder, 2000).

- Casen kan være med til at skabe større sammenhæng og facilitere strukturen i uddannelsen generelt.

\section{Merværdi for de studerende}

- Mere effektiv og sammenhængende læring, fx vil casen på sigt kunne vise den indbyrdes afhængighed mellem sproglige kernefag og ikke-sproglige kernefag og mellem kernefag og fællesfag.

- Et indblik i arbejdsopgaver og arbejdsplatforme, som de studerende evt. kan blive præsenteret for efter endt uddannelse.

- Værdifulde kontakter med virksomheder og organisationer, hvilket på mellemlangt sigt kan være med til at skabe jobmuligheder.

- Fleksibel læring (både med hensyn til tid og indhold).

\section{Merværdi for aftagerne af vores bachelorer}

- De studerende ser i dag ofte virksomhederne som en akademisk genstand, som de har en masse teoretisk viden om. Bachelorerne får ved hjælp af casen et bedre indblik i, hvad en virksomhed er, og hvorledes kommunikationen kan fungere og understøttes i en virksomhed.

- Bachelorer, der ud over sprog og kommunikation også ved noget om elektroniske kommunikationssystemer, og som har kendskab til, hvordan de anvendes.

- Studenterassistance til løsning af forskellige mindre opgaver i virksomheder. Disse opgaver kan evt. indgå i fremtidige caseopgaver.

For at opnå ovennævnte pædagogiske og didaktiske fordele er der dog en del praktiske udfordringer og krav til undervisningsmaterialet, der nøje bør overvejes i forbindelse med udvikling af materialet. Vi har indtil videre identificeret nedenstående områder, som skal tænkes nøje igennem, inden vi går i gang med den endelige udvikling af hele undervisningsforløb baseret på en elektronisk caseopgave.

Casematerialet skal være så virklighedsnært og autentisk som muligt, således at de studerende får en realistisk idé om mulige fremtidige arbejdsopgaver. I den forbindelse er det vigtigt at finde nogle velvilligt indstillede virksomheder, der er interesserede i at stille materiale til rådighed.

Ud over at materialet skal lægge op til praktisk håndtering af kommunikationsopgaver, skal det også på en naturlig måde sætte opgaverne ind i en teoretisk kontekst.

Formålet med opgaverne skal fremgå klart, samtidig med at der skal være plads til kreativitet og selvstændig tænkning. 
Endelig er det vigtigt at sørge for, at forløbet kan styres, så det ikke løber af sporet, og at sikre sig, at der kan gives fornuftig og motiverende feedback/evaluering til de studerende. Dette hænger også sammen med behovet for at planlægge undervisningens form og indhold anderledes end hidtil. Traditionelle katedertimer bør i højere grad erstattes af workshops og studiekredse (gerne styret af de studerende selv).

I denne sammenhæng er det også vigtigt, at lærernes IT-pædagogiske kompetencer udvikles, og at de helt naturlige barrierer, der eksisterer, brydes ned gennem efteruddannelse og ved hjælp af systemer, der ikke kræver IT-viden på højt niveau.

\section{Empirisk undersøgelse af Content Management Systems}

Sideløbende med vores overvejelser om de åbenlyse pædagogiske fordele ved case-forløbet, som vi har diskuteret ovenfor, gennemførte vi en lille empirisk undersøgelse af eksisterende content management systems med henblik på at finde den teknologiske løsning, som ville passe bedst til vores formål. Men inden vi tager fat på det, er det nok på sin plads kort at definere, hvad der forstås ved et content management system (CMS).

Ifølge (Odeum, 2005) er et content management system ".... en samlet softwareløsning, der kan anvendes til at behandle, vedligeholde, koordinere, indeksere og distribuere indhold, og hvor al administration foregår online på inter-, intra- og extranets....”.

Med andre ord er et CMS en ukompliceret platform, hvor en virksomhed eller organisation kan oprette, redigere og styre publicering af det indhold, som virksomheden eller organisationen har valgt at offentliggøre. Samtidig er langt de fleste CMS relativt nemme at lære at bruge, idet de hovedsageligt er baseret på en WYSIWYG-tankegang (What You See Is What You Get). Med andre ord - kan man bruge et tekstbehandlingsprogram, kan man også lære at bruge et CMS.

Et CMS er som hovedregel inddelt i en frontend-del og en backend-del. Frontend er den brugergrænseflade, som brugeren møder, når han besøger virksomhedens eller organisationens website. Backend er den brugergrænseflade, hvor virksomhedens eller organisationens redaktører opretter, redigerer og styrer det indhold, som man har valgt at offentliggøre. Et CMS er baseret på en relationel database, hvor indholdet gemmes, og de fleste CMS gør det muligt at bruge i hvert fald de vigtigste typer af metadata, som i øvrigt kort diskuteres af (Busch, 2005). Mange virksomheder og organisationer går i øvrigt videre og indfører deciderede metadataskabeloner, som er baseret på anbefalingerne i the Dublin Core Metadata Initiative, se også (DCMI, 2005) eller (Leroyer/Simonsen, 2005) for et forslag til en metadataskabelon.

De helt konkrete selektionskriterier, som vi definerede forud for den lille empiriske undersøgelse og test af udvalgte content management systems, var følgende:

- at det pågældende CMS skulle være gratis og open source,

- at det pågældende CMS skulle kunne håndtere mange samtidige brugere,

- at det pågældende CMS skulle være relativt let at installere, administrere og vedligeholde ud fra et undervisersynspunkt,

- at det pågældende CMS skulle være relativt nemt at bruge ud fra et studentersynspunkt, 
- $\quad$ at det pågældende CMS skulle være stabilt og allerede have anvendelse i virksomheder og organisationer.

Den lille empiriske undersøgelse og efterfølgende test omfattede især følgende content management systems, som alle kan downloades gratis og installeres på enten underviserens egne eller universitetets server:

- Typo3 http://www.typo3.com/

- MAMBO http://www.mamboserver.com/

- phpwcms http://www.phpwcms.de/

- Umbraco http://www.umbraco.org/

- Postnuke http://www.postnuke.com/

- Joomla http://www.joomla.org/.

I øvrigt kan man på http://www.opensourcecms.com/ se en lang liste af open source CMS, som man kan teste, før man installerer dem, og der er mange interessante alternativer.

Efter en kort testperiode, valgte projektgruppen MAMBO, fordi vi vurderede, at det både var nemmest at installere, administrere og vedligeholde ud fra et undervisersynspunkt, og fordi det er særdeles nemt at bruge ud fra et studentersynspunkt. MAMBO har efter vores mening desuden også en særdeles brugervenlig brugergrænseflade i admin-delen, og så indeholder MAMBO en række funktionaliteter, som med stor fordel kan anvendes i undervisningen og i virksomheds-casen.

\section{Anvendelse af MAMBO i undervisningen}

Da vi havde installeret MAMBO på en CBS-server og samtidig gjort os de indledende didaktiske/pædagogiske overvejelser, var det på tide at teste det hele på et velvilligt indstillet hold på ca. 25 studerende på en af vores BA-uddannelser på CBS. Pilottesten blev gennemført over 16 lektioner i valgfaget Web Communication i efteråret 2005 og forløb ifølge egne og de studerendes evalueringer særdeles tilfredsstillende.

Hele forløbet var som sagt baseret på den grundlæggende ide, at hver studerende forud for den første lektion var blevet ansat i case-virksomheden BC Mobil, og de havde ved kursusstart allerede fået deres elektroniske ansættelsesbrev samt password og brugernavn.

Selve case-virksomheden BC Mobil A/S er en komplet replika af en autentisk hjemmeside for en mindre virksomhed, der ophørte i 2004. Virksomheden beskæftigede sig primært med salg og service af mobiltelefoner, salg og service af sikringssystemer til banker og sparekasser samt med levering af kommunikationsløsninger til flere større virksomheder og en del kommuners hjemmeplejeafdelinger. Hele virksomhedens opbygning og produktportefølje var at finde på virksomhedens eksisterende hjemmeside, og det hele blev brugt som udgangspunkt i casevirksomheden BC Mobil A/S.

Den overordnede opgave for den nyansatte (den studerende) var i store træk at redesigne virksomhedens gamle hjemmeside og i den forbindelse gøre den nye version af virksomhedens hjemmeside klar til en større international satsning på især de europæiske markeder. Der var derfor behov for at få løst en række analyse- og tekstproduktionsopgaver, som så skulle udføres direkte i 
backend-delen i MAMBO (se Figur 1 nedenfor) og uploades til frontend-delen (se figur 4 nedenfor).

Den interne "private messaging-funktionalitet” i MAMBO viste sig desuden hurtigt at være særdeles velegnet til at give den enkelte eller grupper af studerende ordre om at udføre bestemte opgaver til næste kursusgang. Denne metodik blev anvendt hver kursusgang, og den studerende og holdet som sådan løste forskellige typer af opgaver som passede til kursets indhold og udprøvning. Da kurset var slut, havde BC Mobil en helt ny hjemmeside med nyt opdateret indhold på engelsk, og de studerende havde været igennem en fagligt tilfredsstillende, lærerig og sammenhængende erhvervsrelevant læringsproces, der samtidig gav dem mulighed for at tilegne sig værdifulde kompetencer i at bruge et moderne CMS - alt sammen kompetencer, som både (Anderskouv og Mikkelsen, 2004a-c) og (VTU, 2005) m.fl. efterlyser hos humanistiske kandidater.

Selve oprettelsen af de studerende i MAMBO var uproblematisk. Underviseren havde på basis af navnelister oprettet hver studerende i MAMBO og tildelt dem rettigheder som lokalredaktører i virksomheden BC Mobil. Ved oprettelsen af de studerende fik de automatisk tilsendt en systemgenereret e-mail til deres CBS-e-mail med en velkomsthilsen samt password og brugernavn til deres IT-arbejdsplads på BC Mobil, dvs. backend-delen af MAMBO, og de var således klar til deres første arbejdsdag allerede i den første lektion. Figur 1 nedenfor viser kontrolpanelet i MAMBO efter den studerende har logget ind, og man kan her blandt andet i øverste højre hjørne se funktionaliteten "Private Messaging”, som blev anvendt til at koordinere og uddelegere opgaver som Super Administrator i BC Mobil - altså som underviser. Funktionaliteten "Private Messaging” blev blandt andet anvendt mellem underviser og studerende og mellem de studerende i forbindelse med løsning af opgaver, som gik på tværs af BC Mobils afdelinger, hvor de enkelte redaktører var ansat.

Midt på siden, se Figur 1 nedenfor, har brugeren adgang til i alt elleve primære funktionaliteter, som hver især er repræsenteret ved et ikon. Specielt funktionaliteterne ”User Manager” og ”All Content Items” er relevante at kigge nærmere på i denne sammenhæng, se Figur 2 og Figur 3 nedenfor.

Når underviseren har klikket på "User Manager” kan han her oprette og tildele rettigheder til de studerende, og man kan føre kontrol med de enkelte studerendes aktiviteter på MAMBO ved at se på sidste login-tidspunkt samt ved at se på logfilerne i kontrolpanelet. Pilottesten med de 25 studerende viste, at det kun tager ca. en time at oprette og tildele redaktørrettigheder til et helt hold, og at det var uproblematisk at være ansvarlig for driften af redaktørernes rettigheder, passwords og brugernavne, når først alle var oprettet, og når det hele kørte, som det skulle. 


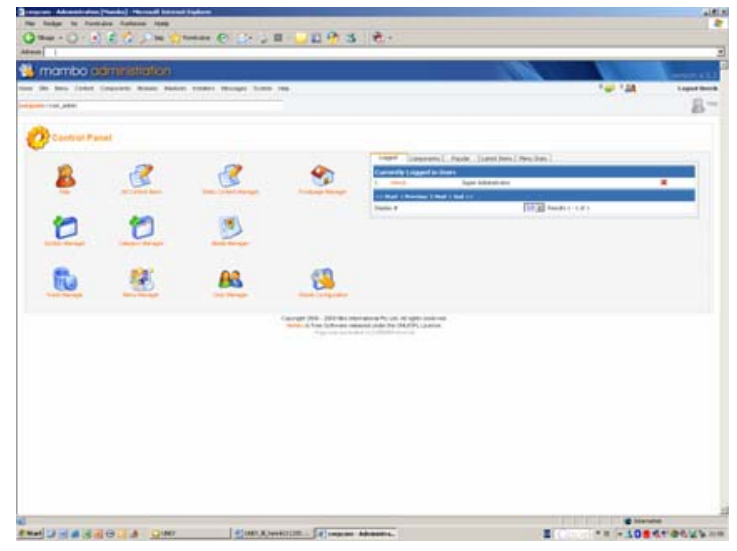

Figur 1. Skcrmbilledet Control Panel

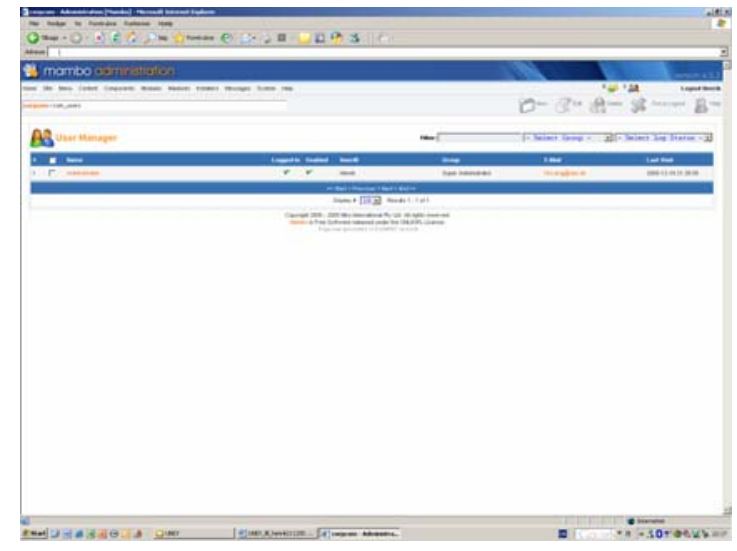

Figur 2. Skcermbilledet User Manager

Også selve anvendelsen af MAMBO som produktionsplatform var relativt uproblematisk. Efter en kort instruktion i principperne for anvendelse af CMS og en grundig gennemgang af de mest anvendte funktioner i MAMBO med særlig fokus på funktionaliten ”All Content Items”, som vist i Figur 3 nedenfor, var de studerende klar til at løse deres første opgave i virksomheden BC Mobil.

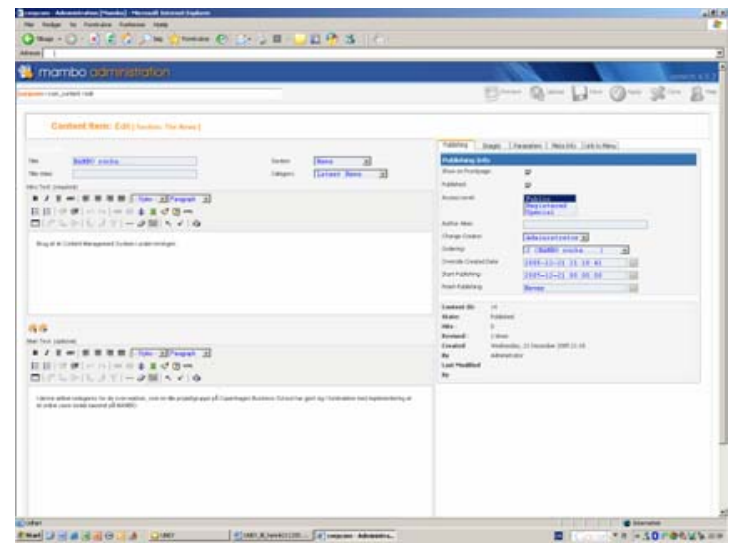

Figur 3. Skcrmbilledet Content Item

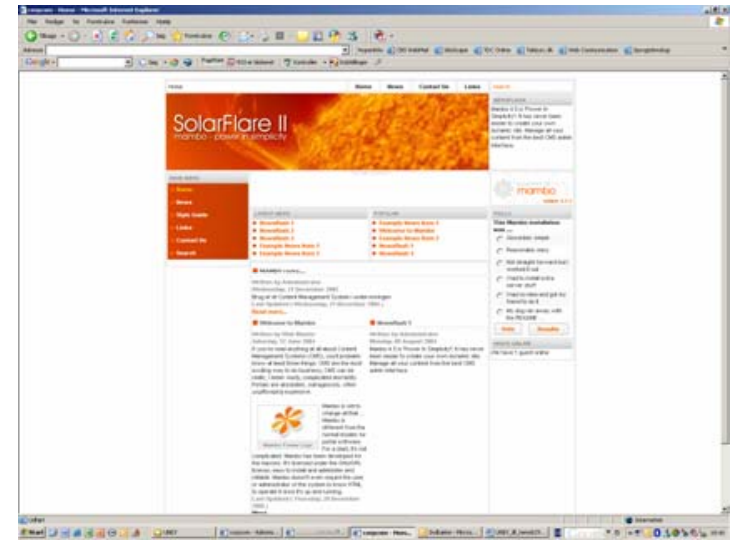

Figur 4. Frontend-delen af BC Mobil

Når den studerende har klikket på ikonet "All Content Items” får han vist skærmbilledet som vist i Figur 3. Dette skærmbillede er det helt centrale skærmbillede i backend-delen af MAMBO, idet det er her, indholdet af virksomhedens hjemmesider oprettes og redigeres. Som det fremgår af Figur 3, indtaster man i øverste venstre hjørne den titel, som det pågældende indhold skal have, ligesom man vælger, i hvilken menukategori indholdet skal vises.

I de to store tekstredigeringsfelter midt på siden skrives hhv. trompeten og brødteksten af indholdet. De to tekstredigeringsfelter fungerer på samme enkle måde som konventionelle tekstredigeringsprogrammer, og der kan både indsættes grafik, indsættes tabeller og links. I højre side af skærmbilledet Content Item, se Figur 3 ovenfor, kan der desuden vælges og indtastes forskellige andre former for vigtige data, fx metadata og en kort indholdsbeskrivelse etc. 
Testen viste desuden hurtigt, at det var relativt uproblematisk for de studerende at bruge MAMBO, især fordi de fleste opgaver blev løst i workshops på klassen, hvor underviseren kunne agere Super Administrator og støtte og guide processen.

Når den enkelte produktionsopgave er løst, klikkes på ikonet ”Save” øverst i højre hjørne, og det pågældende indhold er nu offentliggjort på virksomhedens hjemmeside som vist i Figur 4 ovenfor. Også start- og sluttidspunkt for offentliggørelse af det pågældende indhold kan styres fra højre side af skærmbilledet Content Item. Figur 4 viser i øvrigt frontend-delen af MAMBO vha. den mest anvendte standardskabelon, men man kan naturligvis vælge mellem forskellige standardskabeloner eller endnu bedre selv designe frontend-delen af virksomhedens hjemmeside. Også metasproget i backend-delen kan ændres, og der er adgang til en ret omfattende indbygget hjælpefunktion, hvis der opstår spørgsmål.

På denne måde fik holdet til opgave at udfærdige en række kommunikationsopgaver i BC Mobil, fx:

- forskellige typer af virksomhedprofiler til virksomhedens internet,

- forskellige typer af nyhedsartikler (lancering af produkter, overtagelser, rabatordninger etc.) til virksomhedens internet,

- forskellige typer af pressemeddelelser (bad news og good news releases etc.) til virksomhedens internet,

- forskellige typer af generelle web-tekster (om virksomheden og dens produkter etc.) til virksomhedens internet,

- forskellige typer af intern kommunikation til virksomhedens intranet (funktionskommunikation, social kommunikation etc.),

- forskellige typer af elektroniske nyhedsbreve til virksomhedens kunder.

\section{Konklusion og perspektivering}

De erfaringer, vi har gjort hidtil, viser, at denne type undervisningsmateriale leveret på en CMSplatform i høj grad lever op til en lang række af de nye krav, der stilles til undervisningen på højere læreanstalter. Testen med de 25 studerende viste desuden også, at der synes at være et langt højere studenterengagement og lyst til frivilligt og uden for klasseundervisningen at tilegne sig kompetencer i brug af MAMBO. Desuden afslørede samtaler med de studerende også, at det var optimalt at arbejde med teorien i praksis inden for en virksomheds ramme og via et CMS.

Semesterets test med 25 studerende viste, at læringsprocessen i høj grad blev understøttet af selve CMS-platformen. Ud over at de studerende arbejdede med en sammenhængende case og inden for en virksomheds ramme og i en erhvervsrelevant kontekst, så var selve CMS-platformen desuden stærkt faciliterende for den enkelte studerendes læring, idet vedkommende på basis af flere workshops i klassen blev klædt på til selvstændigt at løse forskellige kommunikationsopgaver og uploade sit produkt til virksomhedens forside.

Rent konkret foregik det ved allerede fra kursusstarten at fastlægge helt klare navngivningsregler for filer og overskrifter, hvorved det blev muligt ved gennemgang på klassen at klikke på hver enkelt studerendes forslag til løsning af opgaven og derved diskutere både gode og dårlige løsninger på klassen. Denne fremgangsmåde var stærkt faciliterende for den enkelte studerendes læring, idet han på denne måde ikke kun lærte af sin egen opgave, men også af andre studerendes opgaver. 
Den første umiddelbare udfordring består nu i først og fremmest at videreudvikle casen. Her foreslår vi et konkret samarbejde med en eller gerne flere virksomheder, således der på sigt kan opbygges en portefølje af erhvervsrelevante og moderne cases, som et eller flere hold kan bruge samtidigt. Desuden vil et sådant samarbejde forhåbentlig også bibringe virksomheden noget godt, idet man sagtens kunne tænke sig, at en dygtig studerendes løsning på et problem kunne være af interesse for den pågældende virksomhed. Det er selvfølgelig også oplagt at udarbejde/få flere typer af cases, som så kan bruges i flere forskellige fag og dermed øge systemets faglige anvendelsesmuligheder.

Den anden større udfordring består i at videreudvikle og skalere selve CMS-platformen, således at platformen efter et kort introduktionskursus til de involverede undervisere umiddelbart kan tages i brug af et større antal undervisere og på flere hold og årgange af studerende.

Afslutningsvis er vi således af den opfattelse, at case-tankegangen kombineret med CMSplatformen er velegnet i næsten alle "produktionsfag”, og at man med en god gennemarbejdet case og en effektiv CMS-platform kan gennemføre en erhvervsrelevant og moderne undervisning i en lang række klassiske BA- og CLM-fag, som fx virksomhedskommunikation, teknisk sprog, økonomisk sprog, juridisk sprog samt naturligvis i langt de fleste kommunikationsfag.

Yderligere udvikling af såvel casen og brugen af MAMBO er således nødvendig og vi har til hensigt at anvende CMS i langt flere fag i fremtiden. Til gavn for både studerende, undervisere og aftagere.

\section{Litteratur}

Anderskouv, Rasmus og Mikkelsen, Inge (2004a). Lokal kompetence-global konkurrence. København: Dansk Industri.

Anderskouv, Rasmus og Mikkelsen, Inge (2004b). Behov for globale kompetencer. København: Dansk Industri.

Anderskouv, Rasmus og Mikkelsen, Inge (2004c). Virksomheder ønsker mere samspil med uddannelsesinstitutioner. København: Dansk Industri.

Busch, Peter (2005). Content Management. http://www.crealize.dk

CBS Learning Lab (2005). Læringsstrategi for Copenhagen Business School - Diskussionsopleg. CBS Learning Lab

DCMI (2005). Dublin Core Metadata Initiative. http://dublincore.org/

Leroyer, Patrick og Simonsen, Henrik Køhler (2005). “Contexte d'utilisation, contexte de communication: la double identité du dictionnaire d'entrepris". I: Proceedings on «Mots, termes et contextes», Brussels, 8-10 September, 2005 (i trykken).

MAMBO (2005). Mambo - power in simplicity. http://www.mamboserver.com/

VTU (2005). Det innovative humaniora og samfundsvidenskab - Opleg til en forskningspolitisk handlingsplan. København: Ministeriet for Videnskab, Teknologi og Udvikling.

Odeum (2005). Hvad er CMS. http://www.odeum.com/.

Phpwcms (2005). Phpwcms. http://www.phpwcms.de/.

Taylor, Paul (2005). Teens more tech savy than ever before. http://news.ft.com/cms/s/628ff726669e-11da-884a-0000779e2340.html.

Typo3 (2005). Typo3.com. http://www.typo3.com.

Wenger, Etienne C. og William M. Snyder (2000) Communities of Practice: The Organizational Frontier. Harvard Business Online: http://harvardbusinessonline.hbsp.harvard.edu 